\title{
Naturalistic Extremes in Al Aswaany's The Yacoubian Building
}

\author{
Hussein H. Zeidanin (Corresponding Author) \\ Department of English, College of Arts, Tafila Technical University, P.O. Box 179, Tafila 66110, Jordan \\ E-mail: husseino_z@yahoo.com \\ Asmaa M. Al Zuraigat \\ Department of Arabic, Faculty of Arts, Tafila Technical University, P.O. Box 179, Tafila 66110, Jordan \\ E-mail: Dr.asmaalzregat@yahoo.com
}

Received: 14-07-2015

Accepted: 25-10-2015

Published: 01-01-2016 doi:10.7575/aiac.ijalel.v.5n.1p.245

Advance Access Published: October 2015

URL: http://dx.doi.org/10.7575/aiac.ijalel.v.5n.1p.245

\begin{abstract}
Emile Zola and other naturalistic novelists such as Stephen Crane, Jack London, Edith Wharton, Frank Norris, John Steinbeck and Richard Wright perceive naturalism as an anti-romantic philosophy dispensing with emotions, sentiments and imagination and parodying the romantic paradigm for idealizing the past and avoiding realities. They view literature as experimental and investigational as science and the novelist as scientist who objectively and methodologically observes and tests the actions and reactions of representative fictional characters under controlled conditions. On the contrary, the writings of the opponents of naturalism like those of A. Plantinga (2010), H. Putnam (2000), J. Kim (2008), J. Spencer (2010), R. Bush (2003), and R. Gerhardt (2010) criticize naturalistic literature for focusing on the negative side instead of the bright side of life, attaching violence and threatening behaviors to the low class people, and representing a pessimistic view of life and human progress. Our paper seeks to recapitulate the epistemological premises of naturalism and the views of its proponents and opponents who debate over the materialism, atheism and sensationism of naturalism. The paper further analyzes the predominant correlation between environment and man, fate and man and biology and man from the perspective of naturalists. The study finds out that the actions and reactions of the fictional characters of Busayna el Sayed and Zaki el Dessouki in Al Aswany's The Yacoubian Building (2003) are not self-determined; rather, they are predetermined by the triad of environment, fate and biology. In addition, the study observes that the absence of hope pervading the characters' lives gives rise to their pessimistic worldviews and stoic behaviors. The study's analysis and findings are based on Al Aswany's text because it, on one hand, epitomizes the naturalistic poetics of classism, fatalism and predeterminism in the Egyptian society. On the other hand, that it was published during the first decade of the twentieth century invalidates the assumption that naturalism is no longer revisited by contemporary Arab writers.
\end{abstract}

Keywords: The Yacoubian Building, Naturalism, Determinism, Fatalism, Escapism

\section{Introduction}

This paper explores Alaa Al Aswaany's The Yacoubian Building (2004) from the perspective of the literary theory of naturalism to understand and analyze the responses of the fictional characters of Busayna el Sayed and Zaki el Dessouki towards social injustices in the Egyptian society during the 1980s and 1990s. Busayna, as a naturalist, expresses her resentment of the patriarchal culture and class system in Egypt; yet, she never challenges her social class and gender identity which she perceives as predetermined realities. This accounts for her naturalistic and pessimistic attitudes. In like manner, though Zaki is discriminated against and subjugated for descending from the ousted royal family of King Farouk of Egypt, he never resists or protests against the new republican regime. The naturalistic ethos of determinism, fatalism and arbitrariness are critically examined and analyzed in this paper. An overview of western naturalism and its manifestations in Arabic literature are provided along with a discussion of its premises and assumptions.

\section{Overview of the Novel}

The novel portrays the modern Egyptian society since the Revolution of 1952 which dethroned and banished the royal family of King Farouk, abolished monarchy in Egypt and brought Jamal Abdul Naser to the presidency of the Arab Republic of Egypt. Most of the events are set in the Yacoubian Building, a metaphor for contemporary Egypt, on one of Cairo's main boulevards where people of the aristocratic, middle and low classes have lived or worked for over seventy five years. Ministers, landowners and foreign manufacturers have taken resident or worked there since the construction of the building in 1934 by the Armenian Jewish businessman Hagop Yacoubian. However, officers of the armed forces and their families have taken over the apartments of the building since the exodus of the Jewish and foreign owners in 1952. The well-to-do owners left the downtown area to suburbs such as El Mohandiseen and Madinet Nasr in the 
seventies and sold their apartments in the building or used them as offices or clinics. Later, a popular community will grow on the roof of the building because of the migration of workers from the countryside to Cairo in search for employment.

The novel dramatizes Taha el Shazli, Zaki el Dessouki and Busayna el Sayed's different responses to the corrupted social, economic and political system of Egypt; Hatim Rasheed and Abdu's conflict with the heterosexual culture of the Egyptian society; Souad's quest of self-realization and actualization; and Hagg Mohammed Azzam's social rise from a shoe-polisher into a self-made millionaire. Though Busayna, Hatim, Abdu and Zaki endure emotional, sexual and physical exploitation on account of their gender, social class or sexual inclinations, they never resist or seek to change their social conditions; rather, they are more likely to escape or evade than to confront or retaliate. Yet, Taha, Azzam and Souad relentlessly strive for their rights and avenge their offenders.

\section{Overview of Western Naturalism}

M. H. Abrams (1999) perceives naturalism as a nineteenth-century post-Darwinian philosophy which assumes that man is a higher-order animal whose character and fortunes are determined by heredity and environment. Personal characteristics, instincts, drives and desires are accordingly subject to the social and economic forces in the milieu into which a person is born. However, Weisberg (2005) introduces naturalism as a synonym or an extension of realism and associates it with the French philosopher Auguste Comte's theory of positivism which considered knowledge as a pure science reinforced by the laws of nature or an objective observation of facts. He also assumes that naturalism has its roots in Hippolyte Taine's scientific approach to the contextual study of art and literature. The French positivist and critic Taine (1873)) asserts that art or visual culture is determined by the qualities of race and the environment in which it is created; and that family genes determine the ways in which people react. He emphasizes that the locale or place in which an individual is brought up must be studied to show how the environment overwhelmingly shapes individuals' actions, identities and responses.

J. T. Farrel (1936) considered the French novelist and art critic Emile Zola a proponent of Taine's theories and "the father of modern naturalism" (251). The foreword Zola wrote to his novel Therese Raquin (1867) became the manifesto of literary naturalism which he further developed and extended at a greater length in other works such as The Fortune of the Rougons (1871), The Experimental Novel (1880) and The Naturalist Novelists (1881) and Germinal (1885). Zola (1980) views naturalism or determinism as "scientific investigation. It is experimental reasoning, which combats one by one the hypotheses of the idealists, and which replaces purely imaginary novels by novels of observation and experiment"; (18) naturalism is a deviation from "a personal fantasy" and a manifestation of "the intellectual movement of the century" (43). In his perception of Naturalistic literature, Zola stresses that "literature does not depend merely upon the author; it is influenced by the nature it depicts and by the man whom it studies"(57). He considers the novelist "an observer and an experimentalist. The observer in him gives the facts as he has observed them, suggests the point of departure, displays the solid earth on which his characters are to tread and the phenomena to develop." (8) Like a scientist, the experimental novelist, Zola believes, is

the one who accepts proven facts, who points out in man and in society the mechanism of the phenomena over which science is mistress, and who does not interpose his personal sentiments, except in the phenomena whose determinism is not yet settled, and who tries to test, as much as he can, this personal sentiment, this idea a priori, by observation and experiment. (57)

He further compares literature to medical sciences in terms of its accurate representation and analysis of reality and clinical study of the heredity laws and social environment which are believed to predetermine human behaviors. In this sense, he argues that "the question of heredity has a great influence in the intellectual and passionate manifestations of man. I also attach considerable importance to the surroundings. I ought to touch upon Darwin's theories" (19). He, therefore, assumes that naturalistic and deterministic writers should scientifically study characters through their instincts, passions and relationships to their surroundings and represent them as being devoid of free will and individuality.

Naturalistic literature, as Donald Pizer (1984) conceives it, is a chronicle of everyday life in a community populated primarily from the ill-educated lower middle class or the lower class characters whose acts of violence and sexual adventures stem from the external determinants of environment and heredity. It is usually set in an urban unheroic place where life is dull, boring and depressing; it dramatizes man's predetermined conflict against nature and man's conflict against himself; it represents free will as an illusion and explores the themes of survival, determinism, chaos and arbitrariness; it questions the indifferent forces of nature, heredity and social conditions to which man is fated. These motifs are addressed in the works of the nineteenth and twentieth-century European and American naturalists such as Emile Zola in his cycle of twenty novels collectively entitled in Les Rougon-Macquart (1871 - 1893), Stephen Crane in Maggie: A Girl of the Streets (1893) and The Red Badge of Courage (1895), Frank Norris in McTeague (1899), Jack London in The Call of the Wild (1903), Edith Wharton in Ethan Frome (1911), John Steinbeck in The Grapes of Wrath (1939), Richard Wright in Native Son (1940) and Theodore Dreiser in Sister Carrie (1990). During the second half of the twentieth century, Asian, African, Latin American and Arab writers were inspired by the philosophical tenets of naturalism upon which they built their scientific study of the factors determining man's actions and reactions. 


\section{Naturalism in Arabic Literature}

Eduard H. Strauch (2001) cites Paul Van Tieghem's definition of naturalism as an extension of realism and a reaction to the developments of urbanization. Emile Zola's fictional and dramatic works suggest that short story writers and playwrights should imitate scientists in their pursuit of discovering the truth.

Our examination of naturalism as a literary approach and a form of realism in Arabic literature concludes that while contemporary Arabic literature conforms to the forms and characteristics of naturalistic western literature, classical Arabic literature departs from it. Al Hamdani (1989) reached the same conclusion in his argument that Arab poets and writers have been influenced and inspired by naturalism since the early twentieth century. He believes though the preIslamic literature is replete with works realistically representing the Arab culture and society at that time, it deviates from western naturalism by proceeding from spontaneity (195). This creative and unique convention of Arab naturalism applies to most of the Umayyad literature like in the love poems of Umar Ibn Abi Rabia, and to the Abbasid literature like in Kitab Al Bukhala (Book of Misers) by Al Jahiz and the love and wine poems of Abi Nuwas. Contrary to naturalism in classical Arabic literature, naturalism in modern and contemporary Arabic literature adopts the basic presumptions and assumptions of western naturalism because of the bridges that have been constructed to bring the two cultures and literatures into dialogue (ibid, 210).

Naturalism in its contemporary western context reveals itself in the works of Jubran Khalil Jubran, Mikhail Nouaima and Mohamed Taymour which address such topics as love, marriage and feudalism. It also finds a clearer expression in The Days (1933) by Taha Hussein, The Return of the Spirit (1933), The Diary of a Prosecutor among Peasant (1933) and My Donkey Told Me (1938) by Tawfiq Al Hakim and The Heart of Lebanon (1947) by Ameen Rihani.

Other naturalistic works are written as a critique of social and ethical issues, autobiographies or an expression of the writer's feelings and emotions. These thematic developments unquestionably indicate that the modern and contemporary Arabic literature has become as deep, realistic and human-oriented as its American and European counterparts.

Since the early twentieth century, issues concerning the countryside have engrossed the attention of many Arab novelists whose novels honestly and sincerely tackled class conflict, relationship between land owners and peasants, and feudal traditions, values and ideals. The country has accordingly created a fertile ground to the issues the writers addressed in their works.

In consistence with the themes and topics of naturalistic fiction in the United States and Europe, modern Egyptian novelists and short story writers Mahmoud Al Badawi, Shukri Ayyad, Yusuf Idris, Saad Mekawy, Mohamed Taymour, Mahmud Tahir Lashin, Yahya Haqqi, Abdul Rahman Fahmi, Naguib Mahfouz, Yusuf Sibai and Mohammad Abdel Halim Abdullah discussed and reflected upon social issues and dilemmas in their works which draw on carefully selected pictures to represent social realities (ibid, 211). Naguib Mahfouz is widely recognized as one of the most prominent contemporary novelists whose works honestly and objectively represent reality. Because some of these writers developed self-magnification and self-gratification, their narrative works became less attached to reality, more self-oriented and more concerned with explaining or justifying events. This has resulted in the failure of writers to imagine the private worlds of other people, reproduce or provide an accurate account of reality, and meet the impersonality of western naturalism (ibid, 212).

Naturalism emphasizes the significance of drawing inspiration from corrupted social realities and depicting paradoxical and incongruous conditions. Pessimism, therefore, characterizes the perspectives of Arab naturalistic writers who critically analyze and respond to the sociopolitical and national contexts of the Arab World. The most pressing political issue they have struggled with for decades is the occupation of Palestine and the displacement of the Palestinians by the Israelis. Ghassan Kanafani's novels Men in the Sun (1963) and All That's Left to You (1966) are considered representative texts of that ideological and political trend. The two novels relate the story of the Palestinian people under occupation, siege and discrimination, manifest their despair and self-regression, and examine the psychological, social and economic ramifications of the Palestinian tragedy. Halim Barakat's novel Six Days, in a like manner, retrospectively and reflectively critiques the sociopolitical and national realities of the Palestinian issue. Other novels epitomize family and generational conflict such as Basima Between Tears (1958) by Abdul-Salam Ojeili, The Disobedient (1964) by Sudqi Ismael and Outsiders in Our Own Country (1972) by Walid Madfai.

N. Abd Al Rahman in Modern Criticism (1979), A. R. Asfar in Literary Theories of the West (1999) and P. B. Al Tayeb and J. A. Assaid (2000) in "Realism in literature" criticized the works of Arab naturalists for lacking the essence of artistic and objective signification as the narrow local environment, in which they are set, does not represent the diversity and heterogeneity of the Arab civilization and culture. The protagonists, they characterize, usually feel constantly defeated in their struggles against reality and make the dilemma of the Arabic novel. On this account, they encourage writers as well as artists to free their novels, plays, movies and songs from the taints of naturalism.

\section{Opponents of Naturalism}

Some critics believe that naturalism as a literary and philosophical movement has failed in Europe, the United States and elsewhere for its concentration on the sensual and voluptuous description of physical realities. It is generally denounced as a doctrine without a reformist mission, philosophy or goal. L. Russ Bush (2003) rejects the naturalistic and atheistic worldview and advocates the merit of the theistic worldview. He assumes that "there is, moreover, in a theistic worldview, a basis and a source for truth outside of and other than from human observation alone.... The real existence of this source, God himself, is the only viable guarantee of the objectivity of truth" (38). 
Likewise, Richard Gerhardt (2010) criticizes naturalism from a theistic point of view. He thinks that "the Christian founders of modern science expected order in the universe because they understood the universe to be the product of a rational Creator. Whereas modern scientific naturalists depend upon that order, naturalism cannot account for it, explain why it is characteristic of the universe" (para. 8). Like other philosophers such as Alvin Plantinga, Gerhardt believes that "naturalistic evolution is self-refuting in this regard, that if the human brain is the product of a random process whose goal was merely survival and reproductive fitness, then there is no reason to trust the conclusions of such a brain" (para. 8).

J. Kim (2008) argues against the naturalized epistemology of W.V. Quine which he attacks for its empirical equation between knowledge, evidence and justification and overemphasis on the interrelation between evidence and theory.

H. Putnam (2000) refutes the naturalistic concepts of the evolutionary epistemology, rationality, cultural relativism and reliability theory which Quine's writings disseminate and promote. Putnam attacks naturalists' metaphysical notion of truth and assumes that it is not only unverifiable but also erroneous.

J. Spencer (2010) dismisses naturalism as "entirely irresponsible. I believe it has irreparably harmed philosophy by eliminating the normative in epistemology and removing epistemology itself from the field of philosophy. Not only has it harmed philosophy, though, it has also harmed science, since it has removed any notions of understandable foundations for science to rest upon" (168).

\section{Characters with Naturalistic Tendencies in The Yacoubian Building}

Busayna el Sayed, who was born to a poor family and grew up in a slum near Cairo downtown, developed a naturalistic character based on the following observations. First, the milieu she lived in determines the future of the dreams she has woven. As a school girl, she studied for a commercial diploma and wished to marry her boyfriend Taha el Shazli, have children and live together in a spacious apartment along way from the Yacoubian building. Unfortunately, her dreams will not come true as she has to quit the school and look for a job upon the insistent demand of her widowed mother who, after her husband dies, cannot manage to provide for the family through her job as a housemaid and the meager pension of her husband. Busayna's long-dreamt marriage to Taha will not be fulfilled either; after the he is denied admission at the Police College by reason of his low birth as the son of a doorkeeper, he joins the Faculty of Economics and Political Sciences at the University of Cairo where he feels socially alienated from and marginalized by his rich classmates. His company of the mosque group and acquaintance with Sheikh Shakir eventually turns him into an Islamic extremist. Soon he learns that love is haram, an Islamic term meaning sinful or forbidden by Allah; and he should marry a religious woman in commitment to the Prophet's Hadith which instructs Muslims to take women in marriage for their religion but not for their beauty or wealth. Because the standards of a good Muslim woman which are set for him by Sheikh Shakir do not apply to Busayna, he breaks with her and marries Sister Radwa.

Second, Busayna develops escapist and defeatist attitudes when exploited, harassed or challenged. For example, the repeated sexual harassments she receives from her employers give a reason for leaving or being fired from the several jobs she has held. This form of escapist resistance will turn into complete obedience to and compliance with the demands of the harassers considering the instructions given to her by her mother who instructs her that "a clever girl can look after herself and keep her job" (42). Fifi, the daughter of a laundryman, also sarcastically explains to her that most employers do that with the girls working for them and that any girl, who declines their sexual advances, is thrown out and a hundred other girls, who do not object, take her place. She further instructed her to take care of her physical appearance, paint her fingernails and toenails, and wear short and revealing dresses. Despite the confusion those instructions and explanations cause to her as a reserved Muslim girl, Busayna defeatedly and unwillingly allows Talal, the owner of a clothing store for who she worked as a saleswoman, to pounce on her from behind, rub up against her and play with her body. In this way, Busayna succeeds to maintain her job for years, make money, receive precious presents from her employers, please and comfort her mother with the money she takes from her. Nevertheless, the financial and social successes she achieves fail to free her from the painful feelings of guilt and remorse she feels over the sins she commits, and the unfaithfulness and betrayal she meets Taha with.

Another example of her escapism and defeatism can be extracted from her stoic and passive protest against the corrupted judicial and political systems of Egypt. As a naturalist, she stoically accepts what happens without complaining or showing emotional, physical or ideological resistance. In her conversation with Taha over the decline of his application to the Police College and the disappointment and frustration it caused to him, she expresses her distrust in the Egyptian judicial system and assures him that bringing a case against the college will not redress his grievances. Instead, she advises him to pursue his university degree in the best college and travel to an Arab country where he can work and make money. She as well warns him not to "come back here till you're rich. And if you never come back, better still" (59). Her suggestion for Taha to travel and advice not to complain or resist express her repressed concern and suspicion about the efficacy of a popular or individual revolution against poverty, dictatorship and corruption.

In another conversation, Zaki wonders whether Busayna loves Egypt or likes to travel and she rationally responds by comparing her experience as a low-class woman with his experience as a foreign educated engineer and a descendant from the ruling family of King Farouk. She reminds him that he has never waited at the bus stop or had taken three different buses to get home; he has never been left to sleep in a tent on the street; he has never been insulted or beaten by the police; he has never spent the whole day looking uselessly for work; and he has never understood what poverty is. On this account, she discloses that she hates Egypt, distrusts and repudiates the patriotic rhetoric of nationalists and wishes to travel far from the hell of life here to Holland or to any other place, where "there's no injustice and doing people out of what's theirs, like here. There everyone gets what's his and people respect one another" (199). Traveling 
or immigration, therefore, represents an escape or shelter for her from the harsh realities she is faced with in contemporary Egypt which, she thinks, belongs to "the people who have money" (59) but not to the poor.

Like Busayna, the fictional character of Zaki el Dessouki in Al Aswany's novel manifests three salient characteristics of naturalists. One characteristic concerns his forgiving and non-vengeful personality. As a public figure descending from the ousted royal family of King Farouk of Egypt, he non-revengefully responds to the abolition of monarchy, establishment of a dictatorial regime, denial of the privileges entitled to him as a person of noble birth and discrimination against him because of his past. He naturalistically opts for retreat, escape and reconciliation instead of confrontation, so he travels abroad to study engineering, forgives his perpetrators and adversaries, consumes alcohol and indulges in illegitimate love with Rabab, Busayna and Christine.

With respect to his private and family life, he uncomplainingly allows his sister Dawlat to intrude into his privacies and forgives her conspiracy to force him out of his apartment. He likewise forgives the accusation and complaint of bringing prostitutes, drinking alcohol and practicing indecencies in his sister's house despite the embarrassment, confusion and harm his subsequent arrest with Busayna causes. In like manner, he never brings a case against his girl friend Rabab for stealing his diamond ring; and he forgives his other girlfriend Busayna for the trick she plays with Malak to take over his apartment after he dies.

The other characteristic concerns Zaki's idealization and romanticization of the past which provides him with an escape from the present. In a nostalgic recollection of his life as a young boy, he rejoices in reconstructing the glorious past of Cairo when it was a Europe-like city whose downtown was clean, safe, smart and swarming with tourists and foreigners. He takes joy and pride in recalling the Automobile Club, Mohammed Ali Club and Gezira Club where he and his childhood friends used to spend their days and nights partying, singing, dancing, drinking and laughing. Yet, he woefully conjures up the memory of the displacement of many foreigners by Abd el Nasser in 1956 when he first threw the Jews out before the rest of foreigners got scared and unwillingly departed Egypt. Since then, he remembers Egypt has been sinking in corruption, poverty and decay. The memories conjured up from Zaki's past reveal a suppressed desire to revive the past and disturb the illusory prosperity, democracy and stability of the present which he is alienated and escaping from.

The third characteristic concerns his deterministic orientation. As a child, he thought he could freely choose and do whatever he wanted, so he planned for his life and was very sure that he would be able to accomplish the plans and purposes he had set for himself. Yet, when he grew into a young man, he discovers that "man controls almost nothing. Everything is fate" (137). This discovery turns him into a fatalist who believes that man is not a chooser or a picker but a slave to what he is destined to be. He, therefore, dismisses free will as a fantasy or illusion man constructs.

\section{Conclusion}

Naturalists view the wars, epidemics, famines, poverty, defeats and conquests occurring across societies, nations, cultures and ages as social phenomena that are predetermined by such laws of nature as conflict, progress, creation and evolution. As soon as individuals internalize the naturalistic ideals of predeterminism and fatalism which are promoted and engendered by the family, religion and culture, they become more satisfied than dissatisfied, more escapist than reformist or conservationist, and more cooperative than competitive. While philosophy rationally explains and accounts for the human nature, literature creatively embodies and reinforces it. Thus, philosophical abstractions grow into social practices in literature. In The Yacoubian Building, Al Aswaany introduces Busayna and Zaki as exemplary naturalistic characters who develop none-revengeful, fatalist and pessimistic view of life and human nature.

\section{References}

Abd Al Rahman, N. (1979). In Modern Criticism. Juhaina for Publishing and Distribution.

Abrams, M. H. (1999). A Glossary of Literary Terms. Heinle \& Heinle.

Al Asfar, A. R. (1999). Literary Theories of the West. Arab Writers Unions.

Al Aswany, A. (2004). The Yacoubian Building, Harper Perennial.

Al Hamdani, S. (1989). Effects of Western Literary Approaches on the Modern Arab Literature. University of Mosul.

Bush, L. R. (2003). The Advancement: Keeping the Faith in an Evolutionary Age. Broadman and Holman.

Farrel, J. T. (1936). A Note on Literary Criticism. Vanguard Press.

Gerhard, R. (2010, April 7). The Failure of Naturalism. Retrieved from http://www.apologetics315.com/

Kim, Jaegwon. 2008. What is Naturalized Epistemology?” Epistemology: An Anthology. Eds. E. Sosa, J.

Kim, J. Fantl and M. McGrath. Malden, MA: Blackwell Publishing. 538 - 550.

Pizer, D. (1984). Realism and Naturalism in Nineteenth-Century American Literature (Crosscurrents Modern Critiques). Southern Illinois University Press.

Putnam, H. (2000). Why Reason Can’t Be Naturalized.” Epistemology: An Anthology. Eds. E. Sosa, J.

Kim, J. Fantl and M. McGrath. Malden, MA: Blackwell Publishing. 314-24.

Spencer, Joseph (2010). Naturalism and is Opponents. Undergraduate Review, 6, 164-168.

Strauch, E. H. (2001). Beyond Literary Theory: Literature as a Search for the Meaning of Human Destiny. Boston: University Press of America.

Taine, H. (1873). The Philosophy of Art: Primary Source Edition. Nabu Press.

Weisberg, G. P. (2005). New Dictionary of the History of Ideas. Vol. 1. Charles Scribner's Sons.

Zola, E. (1880). The Experimental Novel and other Essays. New York: Cassel Publishing. 